\title{
Techno Economic Evaluation of a Hybrid Energy System
}

\author{
D.Sattianadan, R.Sridhar, S.George Fernandez, C.S. Boopathi
}

\begin{abstract}
Use of renewable electricity resources has proved to be a more reliable and cleaner solution now-a-days. Photovoltaic units, wind turbine units have been considered as these are the most commonly used renewable energy generators today, but these generators involve high values of losses and are highly expensive. This paper presents a multi objective optimization using the Matlab GAtool. The algorithm is executed on a test system of 69 buses. The results of the case study show that proper positioning of renewable energy generators and sizing can lead to improvement in voltage profile, reduction in power losses and reduction in cost. Cost analysis of this framework is performed using Homer Pro3.8.1 which shows that this hybrid energy system is more efficient and economical than using of a single renewable electricity generator or combinations of renewable electricity generators of different sizes for a variable load profile. The advantages of this algorithm include its accuracy, calculation speed and the reduced values.
\end{abstract}

Keywords: Renewable energy,optimal sizing and positioning, cost analysis.

\section{INTRODUCTION}

The major source of electricity so far has been fossil fuel, but with the current high rate of depletion, it can last for only about 150-200 years more. This shifts interest to water and nuclear reserves for the production of electricity, but they require vast areas, high maintenance cost and large amount of skilled labor. Nuclear power plants have to deal with the radioactive wastes too additionally. On the other hand, renewable electricity generators like photovoltaic units, wind turbine units, fuel cell units, etc. provides a more reliable, cleaner and quieter solution [1], it has been shown that solar energy with the correct positioning and sizing of the PV can provide easy and cheap electricity to a large area and it is cheap can be affordable for the rural localities for most of the developing or underdeveloped countries of the world. They are the most sought after resources for remote areas like satellite stations, etc. or areas where the conventional resources cannot be used [2], but Renewable Energy generators (REG) usage can lead to various problems like reverse power flow, harmonic distortions, stability problems

Revised Version Manuscript Received on 10 September, 2019. SRM Institute of Science and Technology, Chennai, Tamilnadu, India(Email: sattianandan.d@ktr.srmuniv.ac.in)

R.Sridhar, Department of Electrical and Electronics Engineering, SRM Institute of Science and Technology, Chennai, Tamilnadu, India(Email: sridhar.r@ktr.srmuniv.ac.in)

S.George Fernandez, Department of Electrical and Electronics Engineering, SRM Institute of Science and Technology, Chennai, Tamilnadu, India(Email: georgefernandez.s@ktr.srmuniv.ac.in)

C.S. Boopathi, Department of Electrical and Electronics Engineering, SRM Institute of Science and Technology, Chennai, Tamilnadu, India(Email: boopathi.cs@ktr.srmuniv.ac.in)
D.Sattianadan, Department of Electrical and Electronics Engineering,

$[3,4]$. The effective operation of the REGs leading to an improved voltage profile, reduced losses, cost, etc. depends upon factors like their proper position and their sizing [5-7]. In Ref. [8], the authors have worked on the design and control strategies that can be used on a hybrid energy system using genetic algorithms. In Ref. [9], only the optimal sizing of a $\mathrm{PV}$, wind, diesel hybrid energy system has been done resulting in the minimization of the cost and also a comparison between the costs of this system with or without the use of batteries have been presented. The objective function dealt with minimization of losses and to improve the voltage profile of the system has been presented in [10-13]. All these papers dealt with single objective algorithms which optimize only for a certain objective, but in reality if one position or size gives the best voltage profile, it might not give the best results of power loss and cost. This problem can be solved if a multi objective code is used in which all the objectives can be considered together. Many other techniques have been used in various papers to solve the optimization problem using genetic algorithm in [14-16]. In [17,18] the authors have used power flow algorithms for optimal sizing of the renewable generators at each load bus of a network. The Monte Carlo method and Tabu Search algorithm for optimal sitting of DG has been applied in [19-21]. Most of the papers tend to concentrate more on one objective rather than giving the best possible outcome of all the objectives. Some authors have worked on a new algorithm named HBMO that proved to be a more efficient one [22-26], describe the features of HBMO and its advantages over the other methods. The authors have worked on (HBMO) honey bee mating algorithm for optimizing but again this algorithm tends towards a local optima. In order to avoid this problem and improve the accuracy of the algorithm, the authors of [27] have tried an improved HBMO to get the optimization done. All these papers considered a constant voltage profile. The effect of load variation has been shown on a hybrid energy system but considering only one objective function in [28] The Homer has been used to consider variable load profiles, but with only one objective of minimization of the total overall cost of the hybrid system [29]. In this paper, a multi objective algorithm is used for the optimal positioning and sizing of a PV/Wind/Battery hybrid system. It is tested on a radial network of 69 buses. The branches of the network, which are the most heavily loaded ones require the addition of REGs. Position values for the REGs depending on those highly loaded branches have been tried, but the results obtained from the GA - tool provides the optimal positioning 
and the optimal sizing of the DGs. Proper positioning and sizing of the DGs can lead to improved voltage profile, reduced loss values, but the GA tool gives results for only a constant load profile. This is why Homer Pro 3.8.1 is used which provides a cost analysis of the different frameworks for a variable load profile. The REGs used in Homer Pro 3.8.1 have the sizes equal to the optimal sizes obtained from the GA -tool.

The procedure of the paper can be summarized as follows:

a. Optimal sizing and positioning of the individual REGs have been done on an assumed system of 69 buses using the GA tool.

b. The real power losses, reactive power losses and the minimum bus voltages are obtained for all the combinations of REGs for all the DGs.

c. Cost per kWh electrical energy produced by the REGs is calculated.

d. Cost analysis of the different frameworks has been performed using Homer Pro 3.8.1.

\section{PROBLEM FORMULATION}

The aim of the proposed multi objective algorithm is to find out the optimal location and size of the renewable electricity resources which can satisfy the objectives. There are three objective functions that have been considered. They are explained as follows:

\section{Objective functions}

\section{Improvement of the voltage profile}

Bus voltage plays a major role in the proper functioning of the system which can be described as below:

$$
\mathrm{VRI}=\sum_{n=2}^{n_{b}} \frac{\left|V_{\text {nom }}-V_{i}\right|}{V_{i}}
$$

Where, $n_{b}$ - Number of buses

$V_{\text {nom }}$ - nominal Voltage $=1.0 \mathrm{p} . \mathrm{u}$

$V_{i}$ - Bus Voltage

\section{Minimization of power losses}

The minimization of real power loss can be calculated as follows:

$$
\text { Min. } f_{1}=\sum_{b=1}^{N_{b}} I_{b}^{2} x \quad R_{b}
$$

Where,

$N_{b}$ - Total number of branches in the given radial distribution system

b - Branch number

$I_{b}$ - Current in branch b

$R_{b}$ - Resistance of branch b

$P_{D G \min }<P_{D G}<P_{D G \max }$

$\mathrm{V}_{\mathrm{i} \min }<\mathrm{V}_{\mathrm{i}}<\mathrm{V}_{\mathrm{i} \max }$

\section{Minimization of cost}

The cost per kWh electrical energy generated by the REG can be calculated according to the following model:

$\mathrm{C}(\mathrm{P})=\mathrm{a}+\mathrm{b}^{\mathrm{X}} \mathrm{p}$

Where

$$
\mathrm{a}=\frac{\text { Capital } \operatorname{cost}\left(\frac{\$}{k W}\right) \times \operatorname{Capacity}(\mathrm{kW}) \times \mathrm{G}_{\mathrm{r}}}{\text { Life Time }(\text { year }) \times 365 \times 24 \mathrm{x} \mathrm{LF}}
$$

$\mathrm{b}=$ Fuel cost $(\$ / \mathrm{kWh})+\mathrm{O}^{\&} \mathrm{M} \operatorname{cost}\left({ }^{\$} / \mathrm{kWh}\right.$

where,
LF is the load factor, $G_{r}$ is the annual rate of interest, $\mathrm{O}$ \& $\mathrm{M}$ cost is the cost of maintenance and operation.

The cost function for the PV system can be calculated as

$C_{p v}=\sum_{i=1}^{S_{n}}\left(a_{i} P_{i} \frac{r_{0}\left(1+r_{0}\right)^{m}}{\left(1+r_{0}\right)^{m}-1}+\operatorname{om}\left(P_{i}\right)+\operatorname{rep}\left(P_{i}\right)\right)$

$\mathrm{C}_{\mathrm{pv}}=$ cost of PV panels

$\mathrm{S}_{\mathrm{n}}=$ number of $\mathrm{PV}$ panels

$\mathrm{a}_{\mathrm{i}}=$ unit $\operatorname{cost}(\mathrm{Rs} / \mathrm{Kw})$

$\mathrm{P}_{\mathrm{i}}=$ power capacity

$\operatorname{om}\left(\mathrm{P}_{\mathrm{i}}\right)=$ operation and maintenance cost

$\operatorname{rep}\left(\mathrm{P}_{\mathrm{i}}\right)=$ replication cost

$\mathrm{r}_{\mathrm{o}}=$ interest rate

$\mathrm{m}=$ lifespan of the panels

The cost calculated from this equation can be verified using Homer Pro 3.8.1 .A test system of 69 buses is taken into consideration. Each bus is capable of being attached to a REG. The method to solve the load flow analysis can be summarized as below:

i) At first,the power injections are converted to the corresponding current injections. The branch currents are then formulated as the functions of the equivalent current injections.

ii) A relationship is set up between the bus current injection and the branch currents.

$\mathrm{B}=[\mathrm{BIBC}] \mathrm{I}$

Where $[\mathrm{BIBC}]$ is a bus injection to branch current matrix.

iii) The relationship between the branch currents and the bus voltages is found out.

$[\Delta \mathrm{V}]=[\mathrm{BCBV}] \mathrm{B}$

Where $[\mathrm{BCBV}]$ is the branch current to bus voltage mtrix.

iv) Combining the above two equations, we get the relationship between the bus voltages and the bus current injections.

$[\Delta \mathrm{V}]=[\mathrm{BIBC}][\mathrm{BCBV}] \mathrm{I}$

$[\Delta \mathrm{V}]=[\mathrm{DLF}] \times \mathrm{I}$

The algorithm can be explained as follows:

1. Start

2. Assign two function to each DG one for the size and other for the location

3. Input the test system data

4. Form the BIBC matrix

5. Form the BCBV matrix

6. Find DLF

[DLF=BIBC $*$ BCBV]

7.depending on the type of DG, calculate the effective power loss [SD] caused by it

8 . In the pv system, there is only real power injection. So $\mathrm{SD}=\mathrm{SD}-\mathrm{DSD}$ (real power)

9. for the wind system, there are both real and reactive power.

So $\mathrm{SD}=\mathrm{SD}-\left(\mathrm{DSD}+Q_{d s d}\right)$

$\left(Q_{d s d}=\right.$ reactive power $)$

10. calculate new current $P_{\text {loss }}$

11. calculate real power loss $P_{\text {loss }}=\mathrm{I} * \mathrm{R}$

12. calculate reactive power loss $Q_{\text {loss }}=\mathrm{I}^{*} \mathrm{X}$

13. display real power loss

14. end 


\section{RESULT AND DISCUSSION}

Homer Pro 3.8.1 has been used to validate the proposed algorithm as shown in fig.1. The framework consists of one wind turbine system and two PV systems and it is showing the fig.2. The area is set in order to get the wind resource and solar resource profiles directly. The data entry is done in this profile for 24 hours of the commercial building which is considered as the test system. Fig.3. Gives the information about the load of the building is monitored for 24 hours and tabulated. It displays the daily profile, seasonal profile and yearly profile based on the load which is tabulated. An average demand of $54,779 \mathrm{kWh} /$ day is considered. The solar irradiation at kattankulathur, Chennai, India is shown in fig. 4. Here the results of optimization are shown which is obtained using GA Tool is shown in fig5. The result shows the efficiency of different combinations and shows that the combination of two PVs and one Wind turbine system is the best. Using HOMER Software the system performance is evaluated. It proves that by proper positioning of renewable energy generators and by their proper sizing, there can be an improvement in voltage profile, reduction in power losses and reduction in cost. Figure $6 \mathrm{a}, 6 \mathrm{~b}$ and 7 shows cost results of different combinations with the cost result of hybrid system, it is found that it is most economical

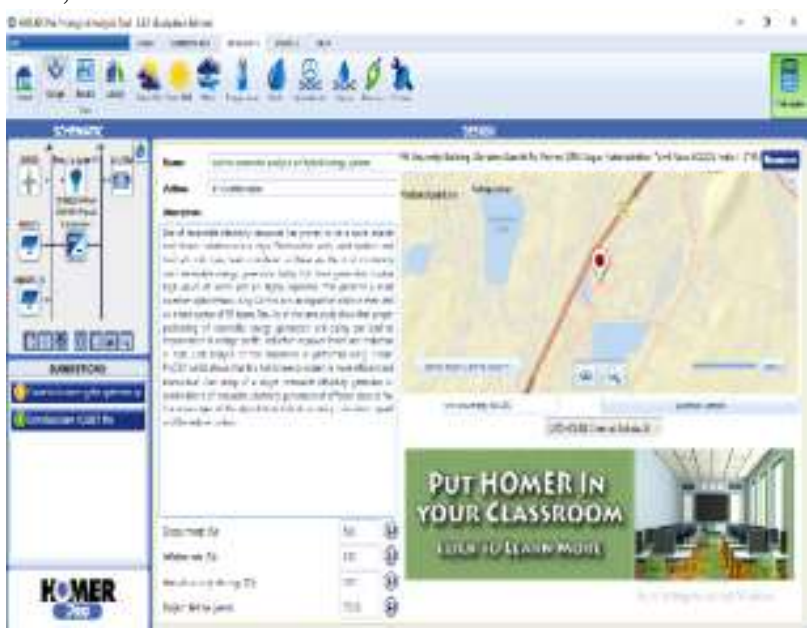

Fig. 1. Proposed Hybrid energy system in HOMER PRO 3.8.1

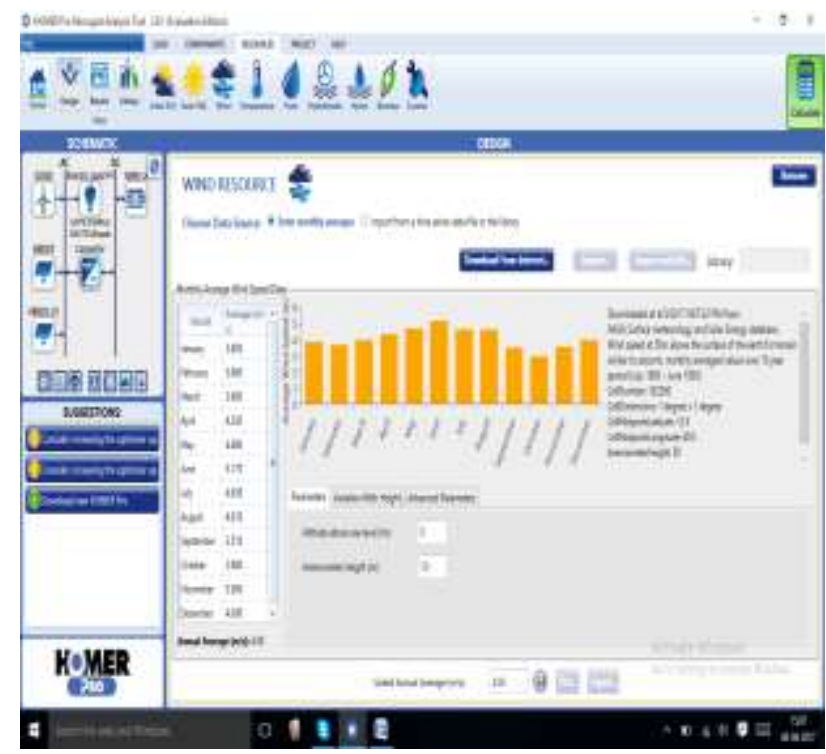

Fig. 2. Wind Resource Profile

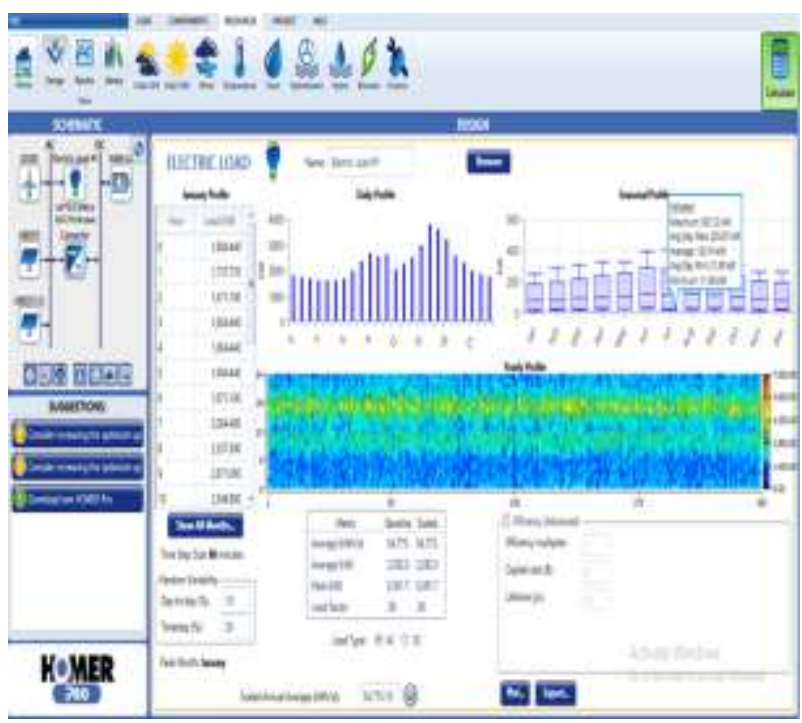

Fig. 3 Load profile of proposed hybrid system

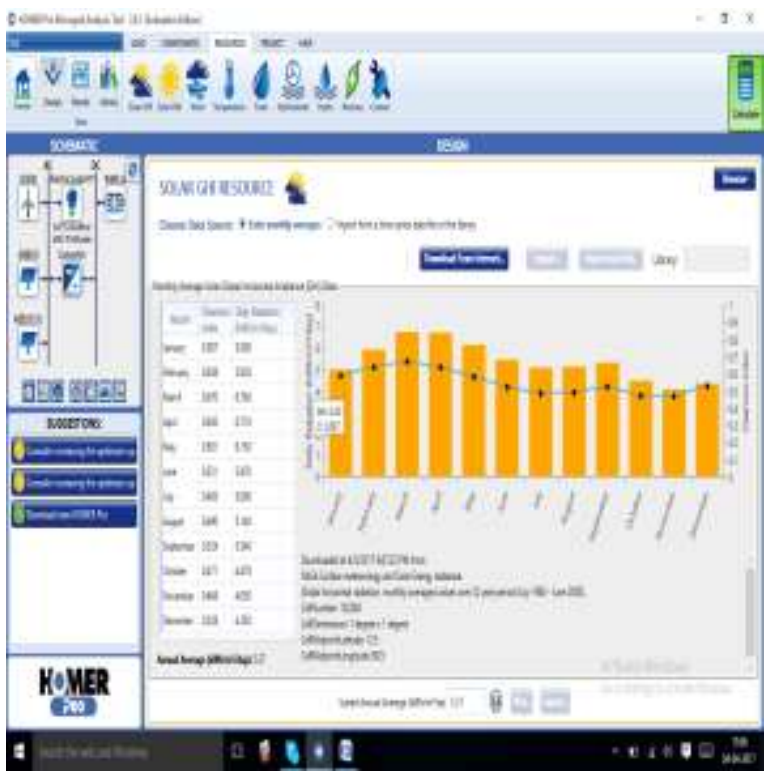

Fig.4. Solar Profile of Kattankulathur District, India

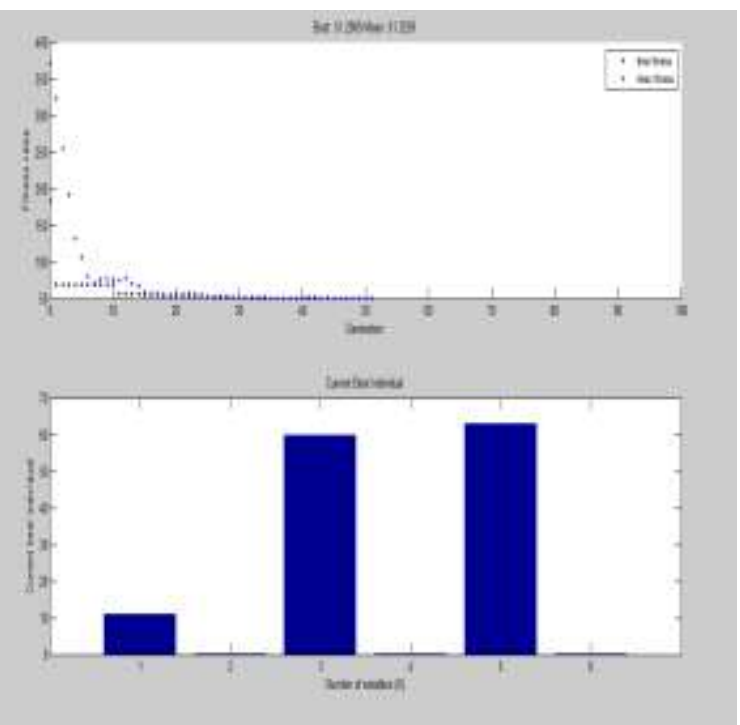

Fig. 5. Ga tool result showing the optimal positioning

Published By: Blue Eyes Intelligence Engineering \& Sciences Publication 


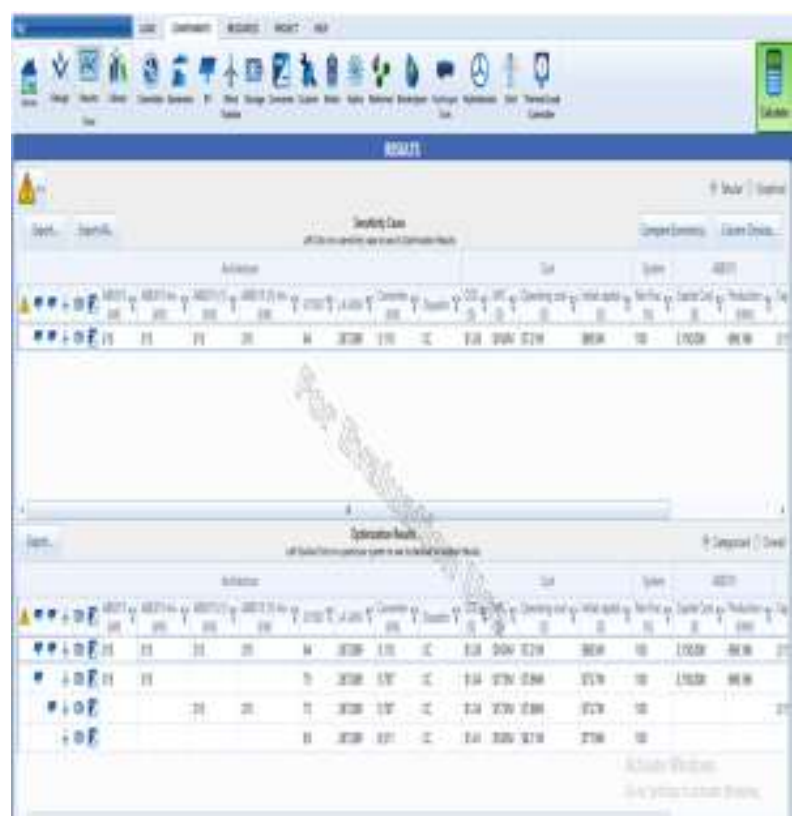

Fig.6(a). Optimization and sensitivity result

Fig.6.(b) Optimization and sensitivity result

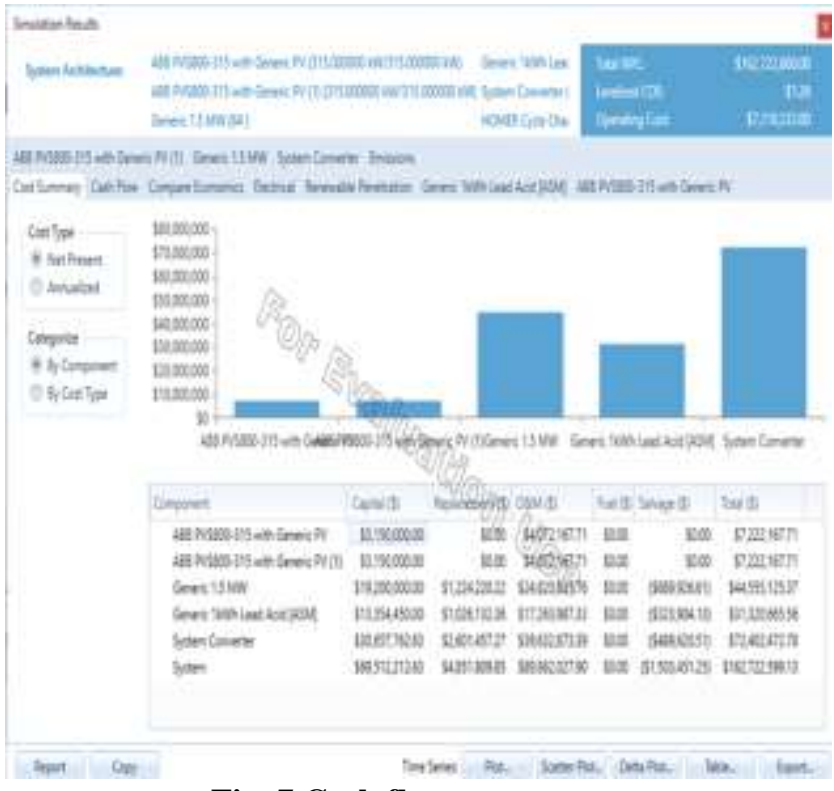

Fig. 7.Cash flow summary

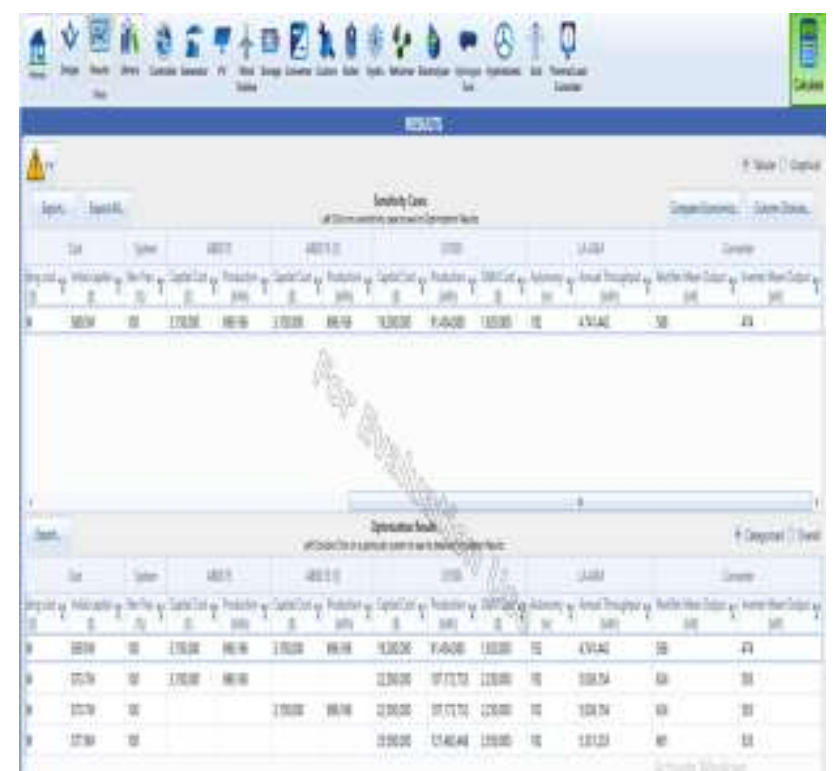

\section{CONCLUSION}

This paper presents the optimal positioning and optimal sizing of DGs using the multi objective genetic algorithm for the minimization of power losses, minimization of cost and improvement of the voltage profile for the most cost efficient framework with a variable load profile can be obtained which can in turn increase the reliability and the efficiency of the renewable electricity generators. The above analysis provides the cost effective solution and a more efficient solution of providing efficient electricity to cut down the endless power cuts and load shedding .

\section{ACKNOWLEDGMENT}

This project is supported by SRM institute of Science and Technology under the scheme of Selective Excellence Initiative 2017. The work has been carried out in renewable energy research lab (RERL), EEE Department, SRMIST

\section{REFERENCES}

1. S. Berclin Jeyaprabha*, A. Immanuel Selvakumar Optimal sizing of photovoltaic/battery/diesel based hybrid system and optimal tilting of solar array using the artificial intelligence for remote houses in India. Energy and Buildings, June 2015, 96, (1), pp. 40-52.

2. D. Sattianadan, V. Kalyanasundaram, S. Vidyasagar, Deepak Kumar Nayak, Roopam Jha, "Maximum Power Point Tracking for a Grid Connected Photovoltaic System Using Sliding Mode Control ", International Journal of Power Electronics and Drive System (IJPEDS), December 2017, 8, (4), pp. 1785-1792,.

3. Zhou Y, Wang L, Mccalley James D. Designing effective and efficient incentive policies for renewable energy in generation expansion planning. Appl Energy 2011 88. (6), pp. 2201-9.

4. Lam HL, Varbanov PS, Klemes J. Regional renewable energy and resource planning. Applied Energy 2011,88, (2), pp. 545-50.

5. Manfren M, Caputo P, Costa G. Paradigm shift in urban energy systems through distributed generation: methods and models. Appl Energy 2011, 88, (4), pp. 1032-48.

6. Connolly D, Lund H, Mathiesen BV, Leahy M. A review of computer tools for analyzing the integration of renewable energy systems. Applied Energy, 2010, 87, (4), pp.1059-82.

7. Rodolfo Dufo-López†, José L. Bernal-Agustín. Design and Control Strategies of PV-Diesel Systems Using Genetic Algorithms. Solar Energy 2005, 79, (1), pp. 33-46.

8. Rachid Belfkira, Lu Zhang, Georges Barakat . Optimal sizing study of hybrid wind/PV/diesel power generation unit . Solar Energy, 2011, 85, pp.100-110.

9. D. Sattianadan, M. Sudhakaran, "Cost/Loss Minimization by the Placement of DG in Distribution System Using GA and PSO - A comparative Analysis", International Review of Electrical Engineering (IREE), Apr 2013, 8, (2), pp.769-775,

10. Nara K,Hayashi Y Y, Ikeda K, Ashizawa T. Application of tabu search to optimal placement of distributed generatotrs. In: IEEE Power Engineering Society winter meeting, 2001, 1, pp.928-23.

11. Hedayati H, Nabaviniaki SA, Akbarimajd A. A method for placement of DG unit in distribution network. IEEE Trans Power Deliv 2008, 23(3), pp. 1620-1628.

Published By: Blue Eyes Intelligence Engineering 
12. Senjyu T, Tona A, Funabashi T. Optimal distribution voltage control and coordination with distributed generation. IEEE Trans Power Deliv 2008, 23, pp.1236-42.

13. Sadeghizadeh M,Rezazadeh A. Using genetic algorithm for distributed generation allocation to reduce losses and improve voltage profile. J World Acad Sci Eng Technol 2008,37, pp.251-256

14. Teng JH,Liu YH,Chen CY,Chen CF. Value-baseddistributd generator placements for swrvice quality improvements. J Electr Power Energy Syst 2007, 29, pp.268-274.

15. Celli G, Ghiani E, Mocci S, Pilo F.A multi objective evolutionary algorithm for the sizing and sitting of distributed generation. IEEE Trans Power Syst, 2005, 20, (2), pp.750-757.

16. Rau NS, Wan YH. Optimal location of resources in distributed planning. IEEE Trans Power Syst 1994, 9, pp.2014-20.

17. Kim JO,Nam SW ,Park SK,Singh C. Dispersed generation planning using improved Hereford ranch algorithm. J Electr Power Syst 1998, 47, (1), pp.47-55.

18. Mendez VHG, Rivier J, de-la-Fuente JI,Gomez T, Marin $\mathrm{J}$, Madurga A. Impact of distributed generation on distribution investment deferral. Int J Electr Power Energy Syst 2006, 28, (4), pp.244-33.

19. Ramirez -Rosado IJ, Dominguez-Navarro JA. New multi objective tabu search algorithm for fuzzy optimal planning of power distribution systems. IEEE Trans Power Syst 2006, 21, (1), pp.224-33.

20. Nara K, Hayashi Y, Ikeda K, Ashizawa T. Application of tabu search to optimal placement of distributed generators.In:IEEE Power Engineering Society winter meeting, 2001, (2), pp. 918-23.

21. Afshar A, Bozog H, Marino MA, Adams BJ. Honey bee mating optimization(HBMO) algorithm for optimal reservoir operation. J Franklin Inst 2007, 44, (5), pp.452-62.

22. D. Sattianadan, M. Sudhakaran, "Optimal Placement of DG in Distribution System is using GA", Lecture Notes in Computer Science (Springer), Dec 2013, 8298, pp.639647.

23. Niknam T.Application of honey bee mating optimization on state estimation of a power distribution system including distributed generators.J Zhejiang Univ Sci, 2008,9, (12), pp.1753-1764.

24. Fathian M, Amiri B, Maroosi A. Application of honey bee mationg optimization algorithmon clustering . J Appl Math Comput 2007, 190, (2), pp.1502-1513.

25. Hadad OB, Afshar A, Marino MA. Honey -bee mating optimization(HBMO) algorithm : a new heuristic approach for water resources optimization .J Water Res Mange, 2006, 20(5), pp.661-680.

26. Taher Niknam, Seyed Iman Taheri, Jamshid Aghaei, Sajad Tabatabaei, Majid Nayeripour. A modified honey bee mating optimization algorithm for multiobjective placement of renewable energy resources. Applied Energy 88 (2011) 4817-4830.

27. B. Ould. Bilala, V. Samboua, P. A. Ndiayea, C.M.F Kébéa, M. Ndongob. Study of the Influence of load profile variation on the optimal sizing of a standalone hybrid PV/Wind/Battery/Diesel system. Energy Procedia, 2013, 36, pp. $1265-1275$.

28. Isidro Padrón, Deivis Avila, Graciliano N. Marichal, José A. Rodríguez, Assessment of Hybrid Renewable Energy Systems to supplied energy to Autonomous Desalination Systems in two islands of the Canary Archipelago. Renewable and Sustainable Energy Reviews, March 2019, 101, pp. 221-230.

29. F. Fodhil, A. Hamidat, O. Nadjemi Potential, optimization and sensitivity analysis of photovoltaic-diesel-battery hybrid energy system for rural electrification in Algeria. Energy, February 2019, 169, (15), pp. 613-624. 